\title{
Indiana Dworkin and Law's Empire
}

\author{
"A new look at ancient problems of judicial romance, philosophical \\ mystery, and academic adventure." \\ -Socrates \\ "Join our Local Hero in this soaring spectacle through the exotic \\ terrain of Modern Thought. Each confrontation more amazing and \\ intriguing than the last." -The Mid-Atlantic \\ "Set to an exciting tempo of incisive writing. You can share the for- \\ gotten experience of Empire-building and marvel at the Palace of \\ Principle." \\ - The Old Republic \\ "An enchanting performance-it will leave you breathless." \\ - John Locke
}

\section{Opening Credits}

Law's Empire. Written, directed, and acted by Ronald Dworkin.* Produced and distributed by Harvard University Press.

Release date: 1986

Running time: $470 \mathrm{pp}$.

Price of Admission: $\$ 20.00$

\section{Allan C. Hutchinson $†$}

\section{The Story So Far (OR JuRISPRUdential Encounters of EARLIER KINDS)}

'Movies are dreams. They're daydreams you often get bad grades over when not concentrating on school work. You grow up being a daydreamer like I did and some day you take those daydreams and turn them into . . . something." -Steven Spielberg ${ }^{1}$

Indiana Dworkin needs little introduction. $\mathrm{He}$ is a juristic adventurer of international fortune and fame. Full of cosmopolitan dash and derring-do, Indy never shirks or ducks a challenge: $\mathrm{He}$ is a Man for All Legal Sea-

- Professor of Jurisprudence, Oxford University, and Professor of Law, New York University School of Law.

$\dagger$ Associate Professor, Osgoode Hall Law School, York University, Toronto, Canada. The editorial assistance of The Yale Law Journal, Jeff Goldsworthy, and Tim Pinos is greatly appreciated.

1. T. Crawley, The Steven Spielberg Story 105 (1983). 
sons. He thrives on and searches out opportunities to risk his professorial neck in crusades to slay academic dragons or to rescue philosophical damsels in distress. He is the classic hero who, armed only with the "bullwhip" of his wit and courage, defends Law's Empire against the intellectual barbarians who work toward its demise and the forces of legal evil that covet its moral prestige. In his own version of The Greatest Legal Story Ever Told, Indy finds himself in a procession of tight corners, close calls, and near-misses which he manages to survive by dint of his own ingenuity and imagination. With a knowing wink and deceptive ease, he reassures us that "I'm making this up as I go." But, not only does he survive these escapades unscathed, he manages to come through a stronger and better person for them, stronger in his conviction about Law's potential and better in his ability to justify its Empire. With each assault on its authority and citadels, Law's Empire is buttressed and its dominion extended. While others exhaust themselves in the hopeless search for the jurisprudential grail, Indiana Dworkin leaps to the defense of existing virtues. All his adventures end at the same place that they began-safe at home in the Palace of Principle.

Law's Empire ${ }^{2}$ is Indiana Dworkin's first full-length feature film and, like his earlier efforts, is bound to be a massive box-office success. It is an action-packed, stand-'em-up-knock-'em-down extravaganza. Those earlier works, Taking Rights Seriously ${ }^{3}$ and A Matter of Principle, ${ }^{4}$ were collections of short videos, little more than a sparsely edited "The Best of ...."Yet, although not essential to the viewer's enjoyment or understanding, a familiarity with the Dworkin genre will enhance the viewer's experience and encourage a critical perspective.

Dworkin captured the public imagination with Taking Rights Seriously. Although his dreams of Empire can be detected in that work, Dworkin's immediate project was to topple the positivist regime and its utilitarian ethic, and to dislodge H.L.A. Hart, its reluctant juristic proconsul, with a naturalist putsch. Dworkin laid the ground for future imperialism in Taking Rights Seriously, but more importantly, Indy performed sufficiently well in these early shorts to establish himself as The Man Who Would Be King and to give warning to all the other aspiring usurpers that he was the one to watch and beat. The significance of these early works must not be overlooked. Reworking the craft and insights of earlier American juristic moguls like Roscoe Pound, Benjamin Cardozo, Alexander Bickel, and Lon Fuller, Indiana Dworkin revived the flagging energies of political jurisprudence and brought his Technicolor touch to

2. R. Dworkin, Law's Empire (1986) [hereinafter by page number only].

3. R. Dworkin, Taking Rights Seriously (1977) [hereinafter Taking Rights Seriously].

4. R. Dworkin, A Matter of Principle (1985) [hereinafter A Matter of Principle]. 
the often drab and dreary world of legal theorizing. Yet he dazzled, but only to deceive. Behind the gloss is the usual collection of hackneyed ideas and dull apologetics.

In A Matter of Principle, Indiana Dworkin consolidated his position and went in search of further adventures and scrapes. He was not short of offers or opportunities; the gauntlet always lay at his feet. Operating on many different fronts, he honed his critical skills and perfected his patented method of turning the debilitating attack to his own advantage. Combining careful preparation with ruthless technique, he located his antagonists' Achilles' heels and tricked them into shooting themselves in the foot. In particular, he engaged and claimed victory over the growing menace of the Literary Fish ${ }^{8}$ and the Utility Monster. ${ }^{6}$ Typically, in these altercations, Indy discovered new and interesting facets of his own political psyche and intellect; he developed the qualities of "equal concern and respect" and the charm of "the chain novel." Further, after apparently defeating his enemies, he did not leave their critical carcasses to be picked over by the circling vultures of future juristic infatuation, but, like the "gentleman of fortune" he is, he extended his hand to the vanquished and enlisted them, suitably reformed and healed, as foot soldiers in Law's Empire. As well as engaging in these titanic struggles, Dworkin took time out to chastise and correct the mistakes of the Empire's judicial ambassadors who had strayed, albeit in good faith, from the imperial path on issues of reverse discrimination, pornography, and free speech. After all was done, the Palace of Principle took on a more finished, if more baroque, appearance and cast its long shadow over the relatively squalid huts and habitats of power politics.

\section{The Main Feature}

\section{A. Old Friends and Old Enemies}

In Law's Empire, Indiana Dworkin offers us a modern epic. If it is a narrative of high jurisprudential adventure, it is also a tale of moral accounting and philosophical proselytizing. It bids us to lift our heads from the trough of mundane legal practice and to gaze upon a juristic splendor that, with will and nerve, could be ours to share. Its appeal is both intellectual and inspirational. No matter how menial or limited our legal task, we must all engage in and become part of the noble enterprise of legal philosophy; lawyers are always philosophers because "[j]urisprudence is

5. See, e.g., Fish, Working on the Chain Gang, 60 TEx. L. REv. 551 (1982).

6. See, e.g., Posner, The Ethical and Political Basis of the Efficiency Norm in Common Law Adjudication, 8 HoFsTrA L. REv. 487 (1980).

7. See A Matter of Principle, supra note 4, at 158-62. 
the . . . silent prologue to any decision at law."8 In this spirit, the key to Dworkin's directorial success has been his cinematographic insistence that "in jurisprudence detail is more illuminating than range." $\mathrm{He}$ foregoes sweeping vistas and instead indulges us in a series of in-depth portraits. A past master of the theoretical fade-in/fade-out and the flashback/flashforward techniques, Dworkin has in Law's Empire produced the film for modernist times-slick, sophisticated, but at the same time, resonant with classical motifs.

While there is no shortage of new academic thrills and spills, there are many familiar antics and amusements to satisfy the Dworkin buff. The old favorites of "articulate consistency,"10 "right answer,"11 and "aesthetic hypothesis"12 not only are back in action, but have moved to front and center in the jurisprudential spotlight, costumed in more formal battledress. To make way for them, "hard cases"1s and the "rules/principles distinction"14 have been abandoned; decorated for gallantry in early campaigns, they are now unsuited to the rigors of more modern legal warfare. Yet many will be delighted or pained to learn that Hercules lives to fight another day, his appetite and ability to solve the most vexing of judicial conundrums undiminished. As Indy's trusted sidekick and judicial alter ego, this character of "superhuman skills, learning, patience, and acumen"15 is an academic one-of-a-kind, something of a cross between Mr. Spock of Star Trek fame and Edgar Bergen's ingratiating dummy, Charlie McCarthy. His singular talent is to reveal "the hidden structure of . . . judgments"16 that eludes lesser mortals. He responds to Indy's assignments with a flexing of his mental muscles and a brief, but respectful "Okey-doke." Not only is Hercules an awesome paragon, with his breadth and depth of legal wisdom, but he embodies a commitment and loyalty that we would all do well to emulate: If we dedicate ourselves to serving Law's Empire, we too can become fulfilled citizens in a just and rewarding communal life. As imperial acolytes, when the going gets tough, we can rely on the tough Indiana Dworkin and the incomparable Hercules to get us going.

The production opens with some quick-fire footage that reminds us that what judges do matters, for to understand legal argument is to know our-

\footnotetext{
8. P. 90.

9. P. 397.

10. Taking Rights Seriously, supta note 3, at 87-88.

11. A Matter of Principle, supra note 4, at 119-45.

12. Id. at $149-54$.

13. Taking Rights Seriously, supra note 3, at 81-130.

14. Id. at 22-28.

15. TAKING Rights SERIOUSLY, supra note 3, at 105.

16. P. 265.
} 
selves better: "No department of state is more important than our courts, and none is so thoroughly misunderstood by the governed."17 After this anguished cry of the frustrated and responsibility-laden leader, Dworkin reminisces about and relives the triumphs of more simple days. He assails the Plain-Facters who hold the law to be a morality-independent matter of historical fact. Wearing the contemporary mask of conventional sense and sculpted from the stone of Hartian positivism ${ }^{18}$ or Finnisian naturalism, ${ }^{18}$ these anachronistic figures make mischief by a dogged use of the "semantic sting." 20 Although Dworkin presents it as little more than a logical dodge, this argument holds that reasoned debate is possible only when parties share an interpretive horizon that contains substantially common definitions of terms. Those who have fallen prey to the semantic sting's "great mischief" thus place all argument into three categories: arguments about the logical consequences of agreed premises; arguments about the borderline meanings of generally agreed upon definitions; and futile discussions based on divergent definitions. Because those who deliver the semantic sting believe that, whatever else it might be, "Law . . . is not a grotesque joke,"21 they reject the suggestion that legal arguments fall into the third category. As a result, they waste their time searching for the generally accepted, but forever elusive, premises which must buttress legal discourse.

Although the Plain-Facters' view commands considerable support, it is disposed of with a minimum of fuss. To Hercules, the Hartians, Finnisians, and other victims of the semantic sting fail to capture the dynamic tension of the interpretive dimension in law. Unlike Michaelangelo's Pieta, with its unique artistry, their works are static and empirical monuments whose accounts fail both as descriptions of how judges struggle to fill the legal gaps, and as prescriptions of how judges should fill such gaps. Where there are complex and subtle disagreements of a theoretical and evaluative nature, these dolmens see only mechanical and empirical disagreements; "we are marked as [their] target by too crude a picture of what disagreement is or must be like."22

\section{B. Jurisprudential Armageddon}

In effect, Indy uses these Plain-Facters as sparring partners to warm up for the more demanding struggle ahead. All interpretations take part

17. P. 11.

18. H. Har', The Concept of LAW (1961).

19. J. Finnis, Natural Law and Natural Rights (1980).

20. Pp. $45-46$.

21. P. 44.

22. P. 46. 
in the ideological fray; there can be no position of moral neutrality or political fence-sitting. The real villains of the piece and threats to Law's Empire are those who have seen the interpretive light, but not its best light. Whereas some have been blinded by its intensity, others have mistaken its source and direction and still others have become enthralled by its kaleidoscopic refractions and optical illusions. In confronting these rogue interpreters, Dworkin follows a familiar strategy in engineering their downfall: Having divided them, he seeks to conquer by engaging them in an ennervating game of jurisprudential cut-and-thrust. They are made to stumble over their own flaws and faults and Indy allows them to surrender in the face of his withering intellectual artistry. By way of insurance, he makes sure that he entices these competitors onto the labyrinthine territory of some cannily chosen legal set-pieces: Riggs $v$. Palmer, ${ }^{23}$ Tennessee Valley Authority v. Hill, ${ }^{24}$ McLoughlin v. O'Brian, ${ }^{25}$ and Brown v. Board of Education. ${ }^{28}$

For Dworkin, interpretation is a constructive affair. The raw data often do not determine the ascription of value, in the sense of allowing a variety of interpretations-value judgments. Thus, interpretation "is a matter of imposing purpose on an object or practice in order to make of it the best possible example of the form or genre to which it is taken to belong."2z The challenge in understanding this dynamic interaction between object and purpose is not to retrieve some original purpose or authorial intention, because the primacy of this task can only be a consequence of prior interpretive decision. Instead, such understanding demands a self-reflective set of interpretive convictions about what counts as the thing to be interpreted, the extent of fit with those data required by any suggested justification, and a body of substantive beliefs about the kinds of justifications that show the data in the best light. Although the nature of the first two convictions must be roughly shared within the relevant community, the third must be relatively independent or else it might not be possible to "distinguish interpretation from invention."28 Fortunately, there is "a fairly uncontroversial preinterpretive identification of the domain of law."28 Although there is more debate about the appropriate convictions of "fit" and "substance," Indy holds that there is a sufficiently abstract

23. 115 N.Y. 506, 22 N.E. 188 (1889) (when statute of wills is silent, common law proscribes murderer's inheriting from victim).

24. 437 U.S. 153 (1978) (snail darter case; appropriations may not be used to modify or repeal environmental legislation by implication).

25. [1983] 1 A.C. 410 (plaintiff received damages after learning about accident to family members and visiting hospital, despite previous rule that generally denied recovery for nervous shock).

26. 347 U.S. 483 (1954).

27. P. 52 .

28. P. 68 .

29. P. 92. 
and uncontroversial "description of the point of law most legal theorists accept so that their arguments take place on the plateau it furnishes":30

Governments have goals: they aim to make the nations they govern prosperous or powerful or religious or eminent; they also aim to remain in power. They use the collective force they monopolize to these and other ends. . . . [T] point of legal practice is to guide and constrain the power of government in the following way. Law insists that force not be used or withheld ... no matter how beneficial or noble these ends, except as licensed or required by individual rights and responsibilities flowing from past political decisions about when collective force is justified.

The law of a community on this account is the scheme of rights and responsibilities that meet that complex standard: they license coercion because they flow from past decisions of the right sort. They are therefore "legal" rights and responsibilities."

On this "plateau," Dworkin scripts and restages the pitched battles of contemporary jurisprudence. Three contending forces of juristic wisdom are pitted against one another in a deadly struggle for control of Law's Empire: Conventionalism, Legal Pragmatism, and Law as Integrity. In short, Conventionalism insists that legal rights and responsibilities can be recognized only when there exists explicit consistency with past decisions, and that "when the force of convention is spent judges must find some wholly forward-looking ground of decision." "32 In contrast, Pragmatism is more skeptical; it maintains that consistency with past decisions has no intrinsic value in deciding what is best for the community's future, but may be relied upon for strategic or expedient reasons. Law as Integrity brings together Conventionalism and Pragmatism, as Dworkin suggests, in a novel and convincing blend. It goes beyond explicit consistency with the legal past by looking to "the principles of personal and political morality the explicit decisions presuppose by way of justification."'3s Legal integrity offers more than the appeal of predictability and procedural equity "by securing a kind of equality among citizens that makes their community more genuine and improves its moral justification for exercising the political power it does." ${ }^{\text {"34 }}$ Law as Integrity supplements the stiffness of conventionalism by taming the wildness of pragmatism. In this titanic encounter, there is never any doubt about the outcome for, we all know,

\footnotetext{
30. P. 93.

31. Id.

32. P. 95

33. P. 96.

34. Id.
} 
nothing and no one could resist Law as Integrity once Indy and Hercules throw their lot in with it. The production's intellectual excitement and moral satisfaction come from the bravado and sheer elan with which our heroes vanquish Law as Integrity's seemingly invincible and mighty opponents.

Marching under the banner of "Law is Law," Conventionalism is an essentially backward-looking movement; it insists that legal rights are the product of existing legal conventions and nothing more. When novel cases arise and conventions are incomplete, there are no legal rights to be enforced, but only a strong judicial discretion to engage in forward-looking justification. Although Jules Coleman, ${ }^{36}$ David Lyons, ${ }^{36}$ and Philip Soper $^{37}$ number among the conventionalist ranks, Indy gives this popular approach short shrift. Teasing them into the maze of Elmer and his friends, he defeats them with one of Hamlet's favored tactics:

I must be cruel only to be kind. . . .

For 'tis the sport to have the engineer

Hoist with his own petard, and't shall go hard

But I will delve one yard below their mines

And blow them at the moon. ${ }^{38}$

Paradoxically, Indy demonstrates that conventionalists "pay more attention to so-called conventional sources of law like statutes and precedents than conventionalism allows them to do."38 Legal practice shows that judges, in novel cases, do not abandon or make strategic resort to the law. Instead, they struggle to extrapolate from it by way of principled consistency rather than precedential convention. Furthermore, even if conventionalism did fit legal practice, it does not provide a decent justification for it. Its alleged virtues of protecting settled expectations and facilitating social coordination are fraudulently preserved, for predictability is but one ingredient, competing primarily with flexibility, in a richer mix of political qualities. Conventionalism prevents the judge from making that balance by insisting on too rigid a view of past legal practice "because any relaxation would inevitably involve the defeat of publicly encouraged expectation." 10 In short, Indy wins by demonstrating that Conventionalism is really a misguided form of Law as Integrity and can never prosper until it recognizes that and comes over to Indy's side.

35. Coleman, Negative and Positive Positivism, 11 J. LEgal Stud. 139 (1982).

36. Lyons, Principles, Positivism, and Legal Theory (Book Review), 87 YALE L.J. 415 (1977).

37. Soper, Legal Theory and the Obligation of a Judge: The Hart/Dworkin Dispute, 75 Mich. L. Rev. 473 (1976).

38. W. Shakfspeare, Hamlet, act III, scene iv, lines 180, 208-11.

39. P. 130.

40. P. 150. 
Having dispensed with Conventionalism, Indy turns to the forwardlooking Pragmatists. Committed to liberation "from the dead hand of the past and the fetish of consistency,"41 Pragmatists decide what is best for the community; as reference to past decisions is by way of strategy and not principle, judges should deviate from clear, but bad precedent. Again, Indy lures his adversaries into his chosen set-pieces and exposes the pragmatists' descriptive and prescriptive flaws. To gain descriptive credibility, they would have to support the claim that, in problematic cases, judges "who worry about problematical statutes and precedents ... [practice] some unmotivated form of deception." ${ }^{\text {22 }}$ As a prescriptive matter, they defeat themselves: By failing "to take legal rights seriously . . . as trumps over . . . the best future properly understood,"43 they leap off the "plateau" of jurisprudential conflict to their scholarly deaths. But, instead of letting the Pragmatists join earlier generations of legal lemmings in the canyon of failed theories below, Indy invites them to play a highstakes game of Political Virtue on his "Solomonic checkerboard." planning a symbolic embarrassment for the earnest Pragmatists, Dworkin hopes to attract even more recruits for Law's Empire: It is a contest of pure Garrollian magic.

Imagine a debate on abortion. The antagonists are implacably opposed. To break the impasse, abortion is made illegal for pregnant women born in even years, but not for those born in odd years. Dworkin shows that the Pragmatist ought to be attracted to this "checkerboard solution" as both sides would prefer it to total defeat. Yet, while some compromises might be acceptable, such as only allowing abortion after rape, this checkerboard solution is unprincipled and, therefore, wrong: "each point of view must be allowed a voice in the process of deliberation but . . the collective decision must nevertheless aim to settle on some coherent principle . . . [and any] compromise must be . . about which scheme of justice to adopt rather than a compromised scheme of justice."45 The Pragmatists' cry that the state may be acting in an unprincipled way, although the individual legislator may be faithful to a coherent personal morality, is seized upon by Indy as a fatal opening through which to deliver his jurisprudential coup de grâce. Law as Integrity "takes the community itself as a moral agent." ${ }^{38}$ Indeed, political legitimacy is not to be secured in social contracts and the like, but in "fraternity, community, and

\footnotetext{
41. P. 151.

42. P. 159.

43. P. 160 .

44. P. 184

45. P. 179.

46. P. 187.
} 
their attendant obligations." political association that goes beyond bare similarity of interest and aspires to fraternal status. Although people have no need to love each other, as "this would mean the extinction not the universality of love," ${ }^{48}$ they must recognize that group obligations are special, that they are personal and not owed to the group as a whole, that each member must be concerned for the well-being of others, and that that concern must be equal for all members.

What does this mean for political practice and organization? Indy's answer is predictably predictable. Dismissing the possibility of "community as a matter of circumstance and as a matter of rules," ${ }^{48}$ he champions "the community of principle":

[M]embers of a genuine political community . . . accept that they are governed by common principles, not just by rules hammered out in political compromise. Politics ... is a theater of debate about which principles the community should adopt as a system ... not the different story . . . in which each person tries to plant the flag of his convictions over as large a domain of power or rules as possible. . . . So each member accepts that others have rights and that he has duties flowing from that scheme, even though these have never been formally identified or declared. . . . [T] hese obligations arise from the historical fact that his community has adopted that scheme, which is then special to it, not the assumption that he would have chosen it were the choice entirely his. In short, each accepts political integrity as a distinct political ideal and treats the general acceptance of that ideal, even among people who otherwise disagree about political morality, as constitutive of political community. ${ }^{50}$

With his typical feel for realpolitik, Dworkin concedes that integrity might not hold much sway in a political community that was "abstract and timeless" and "perfectly just and fair." Bu But it does represent the best interpretation of "a morally pluralistic society." 62 Accordingly, Indy's Janus-faced Law as Integrity puts paid to the challenge of the backwardlooking Conventionalists and the forward-looking Pragmatists: He defeats both by becoming both. All that now remains for Dworkin and Hercules to do is to complete the rout by revealing the detailed route through the doctrinal maze of Elmer and his friends to the Palace of Principle and, by

\footnotetext{
47. P. 206.

48. P. 215 .

49. P. 210 .

50. P. 211.

51. P. 216.

52. P. 213.
} 
so doing, to enhance the power of Law's Empire. They give us a sneak preview of "the unfolding political narrative"ss that is contemporary legal practice.

\section{Through the Maze}

Reflecting the lawyer's cultivated disregard of history, Law as Integrity does not seek to recapture the legal past, but to reconstruct it for the present as "a single unified novel that is the best it can be." In this way, judges are "novelists with epics in mind." ment with political judgment, Indy dispatches Hercules on a series of doctrinal excursions. His first voyage of discovery is through the tortious terrain of the McLoughlin Challenge. ${ }^{56}$ After an arduous tour, Hercules completes his labors by declaring that the best interpretation of the emotional damage cases is that compensation is available if emotional injury is "directly caused by careless driving and foreseeable by a reasonably thoughtful motorist." chest is not the choice of the right answer, but the cultivation and adoption of the correct interpretive attitude: "Law's empire is defined by . . . an interpretive, self-reflective attitude addressed to politics in the broadest sense." $A$ A different decision is unremarkable provided that the judges were "trying to find, in some coherent set of principles about people's rights and duties, the best constructive interpretation of the political structure and legal doctrine of their community."

Having laid out the required interpretive mind-set of those who serve Law's Empire, Dworkin proceeds to lead us along the common law, statutory, and constitutional pathways of the imperial labyrinth that legal integrity has illuminated. He begins by dealing with the economic approach to the common law; his critical moves are well-known and wellrehearsed. ${ }^{60}$ Although meeting a reasonable threshold of doctrinal fit, the justification of wealth as a cherished value is indefensible as an ethic for social or personal morality. However, with characteristic theoretical thrift, Indy argues that market-simulating behavior is defensible from a more egalitarian perspective. Although there is no general duty for people to act always to increase communal happiness, is there not, he asks, "a duty to take others' interests as of equal importance ... when abstract legal

53. P. 225.

54. P. 229

55. P. 409.

56. See supra text accompanying note 25 .

57. P. 258.

58. P. 413.

59. P. 255.

60. See A Matrer of Principle, supta note 4, at 237-89. 
rights conflict?"'1 From the variety of equality theories on offer, Dworkin opts for "equality of resources"-not a constant levelling of resources, but a continuing effort to compensate the less talented beyond what their market transactions produce. This "fits our legal and moral practices no worse [than any other] and is better in abstract moral theory." Con Consequently, if rights conflict, we should forego our plans when the damage to our overall life-plans will be less than the damage to others'. Furthermore, if resources are fairly evenly divided, damage is to be assessed by "comparative financial harm," pared to pay the other not to carry on with her plans.

Although a direct repair to equality is appropriate in common law cases, it becomes less so in conflicts arising under statutory schemes. Armed with a whole host of assumptions about the legislative process, Dworkin has Hercules wend his way through the fragile environment of the Snail Darter Clash. As an intellectual diversion, Hermes makes a cameo appearance as the mythic hero of those who seek to interpret a statute by discovering the communicative will of the legislators. Hermes is "just as patient" as Hercules and "almost as clever." Their encounter is rather tedious and contrived, however, for Hermes is in fact "Hercules" twin," albeit an inferior relation who can only make something of himself if he emulates the Herculean method. The upholding of Law as Integrity means that "Hercules interprets not just the statute's text but its life, the process that begins before it becomes law and extends far beyond that moment. He aims to make the best he can of this continuing story, and his interpretation therefore changes as the story develops."

Finally, Dworkin permits Hercules to lead us across the Olympian range of the Constitution and back home to the heartland of Law's Empire. Our training in the statutory foothills of Law as Integrity has prepared us well for this climb and its more rarefied philosophical atmosphere. As the Constitution is the foundational law, its interpretation must both fit the most basic institutional arrangements of political power and be justified by abstract political theory. ${ }^{67}$ In the climb to the interpretive summit, Indy and Hercules clamber over the exhausted bodies of earlier failed expeditions, like those of the active/passive and liberal/conservative interpretation theories. The last obstacle to be surmounted is the Brown Saga. After much huffing and puffing, Hercules declares that, although

61. P. 296.

62. P. 301.

63. P. 306.

64. P. 317 (emphasis added).

65. P. 337.

66. P. 348 .

67. P. 380 . 
the Constitution does not mandate a singular conception of equality, "it insists that each state recognize certain rights qualifying any collective justification it uses." ${ }^{\text {"88 }}$ Read in the best light of contemporary legal practice, state-imposed racial discrimination is unconstitutional. Moreover, legal integrity suggests a justifying principle of "banned sources" that can make sense of the Fourteenth Amendment generally: "people have a right . . . that preferences that are rooted in some form of prejudice against one group can never count in favor of a policy that includes the disadvantage of that group." ${ }^{\text {"8s }}$ Bringing together popular conviction, national tradition, and philosophical sophistication, Hercules interprets the Constitution as the "parent and guardian of democracy." The summit has been reached, the principled pilgrimage is at an end and Indy's moral mission is almost complete.

Atop the constitutional Olympus, Law's Empire stands before us in all its principled majesty and splendor. Yet, as if this magnificent sight were not enough to sate the head and heart, there stands behind it a "mysterious image" of "present law gradually transforming itself into its own purer ambition." "71 Indeed, Indy's epic ends fittingly with a rush of unparalleled jurisprudential aestheticism, a touch of the Dworkinian divine. Unconstrained by commitments of institutional arrangements and normative conceptions, pure legal integrity escapes its earthly bounds and realizes the vision of social justice that is adopted only in part at present. The Palace of Principle stands in the shadow of this metaphysical Mecca. Indy's preeminent place in this perfect pantheon of jurisprudential greats is assured:

The courts are the capitals of law's empire, and judges are its princes, but not its seers and prophets. It falls to philosophers, if they are willing, to work out law's ambitions for itself, the purer form of law within and beyond the law we have. ${ }^{22}$

So utopian legal politics is . . . law still. . . . But the dreams are competitive, the visions are different, choices must be made. . . . No coherent program may take hold for long enough among enough people; we may be left in the hands of law's cunning after all. . . . But philosophers are part of law's story even then ... for their arguments . . . remind the profession of the pressure of law beyond law, that the imperatives of integrity always challenge today's law
68. P. 382 .
69. P. 384 .
70. P. 399.
71. P. 400 .
72. P. 407. 
with the possibilities of tomorrow's, that every decision in a hard case is a vote for one of law's dreams. ${ }^{73}$

\section{The Reviews}

"[T]he trouble with serious film criticism today is that it is too serious."

\section{The Unseoing Eye \\ (From The Journal of Film Optics)}

. . William Shakespeare was always a man (men?) ahead of his time. He would have had the measure of Dworkin and his fellow juristic directors:

The lunatic, the lover, and the poet,

Are of imagination all compact:. . .

And, as imagination bodies forth

The forms of things unknown, the poet's pen

Turns them to shapes, and gives to airy nothing

A local habitation and a name.

. Such tricks hath strong imagination. ${ }^{75}$

The "lunatic" guild of traditional juristic film-makers presents us with a bewildering array of "strong" and "tricky" images and ideas. Yet, for all their differences, they share much more than meets the eye. Their practice of their craft coheres, not in the range of their visual presentations, but in the fixity and focus of their stare. Like many of his colleagues, Dworkin gazes at the world and misses much of its sensual resonance and historical complexity. An eclectic balance of the senses is sacrificed to the hegemony of rational sight.

The jurisprudential gaze is simply one of many ways of confronting and understanding the world. Sight seems most immediate and simultaneous and, therefore, most neutral and reliable. In modern times, the power of the eye has withered almost all in its gaze. In the popular mind, the power and prestige of science is dependent on the extent to which we celebrate the epistemological primacy of sight-"seeing is believing." Much scientific wisdom has it that, if only we look hard enough and in

73. Pp. 409-10.

74. D. Macdonald, ON Movies 25 (1969).

75. W. Shakespeare, A Midsummer Night's Dream, act V, scene i, lines 7-8, 14-18. 
the right places, the universe will reveal its secrets to us; the unblinking eye will illuminate dark corners of existence. The use of such stratagems as "double blinds" to counteract prejudice works to underline, not modify, the reliance on the visual method. Clearly, the Cartesian icon still holds contemporary society in its spell: The "objective observer" is the doorkeeper at the temple of scientific truth. Within such a culture, the attainment of knowledge is a clinical and voyeuristic activity.

Yet, in all this, the politics of seeing are overlooked or ignored. Vision is deformed by interest and perspective; there is no image that is not precensored. What we believe is not what we perceive and what we perceive is not what we see; we see with much more than our eyes. When we "look and see" more happens than the passive physical connection between light waves and optic nerves. To "look and see" involves a whole apparatus of mental images, intellectual habits, social assumptions, imaginary constructs, and, often, a wilful act of attention. The "male" stare of the Dworkinian eye distorts the world in at least two ways: It objectifies and desensitizes the world of personal relations and it places part of the world out of sight.

The eye sees, but it does not always understand. By honing our visual skills at the expense of our other senses, we lose in intimacy and engagement what we gain in detachment. The rational eye divests people of their history and their experience: It breeds estrangement and alienation. Yet this lack of involvement in the rich emotions of life enables a distanced control. By freezing and fixing the fluidity of social life, the staring eye is better able to control it. The words of Susan Sontag highlight the shared ideological shortcomings of photography and jurisprudence: "Through photographs, the world becomes a series of unrelated, freestanding particles .... The camera makes reality atomic, manageable, and opaque .... [T]he habit of photographic seeing-of looking at reality as an array of potential photographs-creates estrangement from, rather than union with, nature."76 In Dworkin's world, there are no settled relations, bonds of dependency, nor lasting ties. It is the moral terrain of middleclass America, where a comfortable isolation is interrupted by occasional confrontations that are quickly defused, before life returns quickly to normal. It is a robust world in which people stand alone and only form alliances to further their own interests. Indeed, Indy himself represents the epitome of the good imperial citizen: an independent and decisive spirit who has the moral courage and foresight to know what integrity demands. In short, he is the Man of Principle.

The other way that the jurisprudential stare affects the representation

76. S. Sontak, ON Photography 22-23, 97 (1977). 
of the world is through its artful filtering out of certain images and interests. For, as we all know, a way of seeing is always a way of not seeing; sight and blindness are simultaneously present. Jurisprudential cinema is the drama of the visible and the invisible. It is often the silences that speak most and the spaces that reveal most. Indeed, for thirty percent of the time that a film is on the screen, the screen is blank. So it is with Law's Empire. It is an almost exclusively male affair; Dworkin's metaphysical commitments conceal the man-made and man-serving construction of reality by making women's experience and standpoint unseen or trivial. In Law's Empire, women are best represented when they are absent. Those women who do make it to the silver screen are stereotypically "female." In his romp through the jurisprudential jungle, Indy encounters only five women: the distressed and nervous Mrs. McLoughlin, ${ }^{77}$ the dimwitted Senator Smith ${ }^{78}$ the rebellious daughter, ${ }^{78}$ and Lear's daughters, the savage Goneril and the treacherous Regan. ${ }^{80}$ Law's Empire is a male bastion in which women must become "as important as men"81 to be recognized as its citizens.

In a paradoxical sense, Law's Empire is a land of the blind in which the one-eyed lawyer has become king. Because people are reduced to principled dependence, the ability of lawyers to see principles has given them power. Yet the jurisprudential gaze not only fails to see that there are many different scenes to shoot, locations from which to film, and cameras to use, but it also uses the glassy stare of ahistorical reason to the exclusion of other ways of being in and reacting to the world. The project of radical jurisprudence must be one "of jamming the theoretical machinery itself, of suspending its pretension to the production of truth and of meaning that are excessively [uniocular]." 82 It must strive to open up our thoughts to the manifold other ways of experiencing and living in the world. Rather than focus exclusively on the relating individuals, attention must shift to include the more subtle, sustaining, and often elusive character of the relation itself. We must explore and expand the rich and rewarding possibilities for intersubjective experiences. An acceptance of intersubjectivity helps us to come to terms with our vulnerability to and dependence on others, our commitment to and responsibility for others. By viewing the individual self as constituted in and through intersubjective experience, we can more fruitfully understand the notions of autonomy and solidarity; criticism and commitment, innovation and connection can

77. P. 24.

78. P. 321 .

79. P. 205.

80. P. 15.

81. P. 204.

82. L. Irigaray, Speculum of the Other Woman 78 (1985). 
be mutually supportive. By emphasizing intersubjectivity, we can better avoid the over-socialized fate that an unrelieved communitarianism promises and the splendid anomie that a full-blooded liberalism has effected.

\section{Through the Lens Bestly \\ (From Film Community)}

. . . Dworkin's directorial style is self-confessedly of the "best light" school of jurisprudential cinematography. He takes very seriously the idea that "interpretation strives to make an object the best it can be." only adopts this as a narrative injunction, but also projects this preference onto Indy such that his juristic credo demands "the best justification of legal practice as a whole." and filters, Law's Empire has a surreal and sentimental gloss. Dworkin's art does not mimic legal life, but idolizes and fantasizes it as an almost perfected project of human endeavor. Of course, all filming requires cameras to be situated somewhere and operated by some directing eye. Yet, while the "worst light" school of jurisprudential cinematography is excessively bleak and pessimistic in its imagery and symbolism, the "best light" approach wants to see many more silk purses than sows' ears. Its optimism is contrived and ultimately self-defeating.

While many think of the U.S.A. as becoming ever more the United States of Anomie, Dworkin gazes upon it and represents it as a United States of Association. Where others see despair and isolation in American political and social life, Dworkin sees an enviable community of personal contentment and social solidarity. Dworkin manages to effect a spiritual aestheticism in a world of moral asceticism. Indeed, Law's Empire is portrayed as a civic community of fraternal responsibility, a moral agency of principled proportions. Bonded together by the political virtue of integrity, Law's Empire is "a special form of community, special in a way that promotes its moral authority to assume and deploy a monopoly of coercive force."Bs Yet, no matter how lyrical or rhapsodic the quality of Dworkin's political cinematography, it is simply impossible to ignore experience sufficiently to give credence to this fraternal imagery. As Dworkin says of other communal tropes, it "rings hollow as an expression of fraternity."

The fraternal essence of Law's Empire is the existence of associative obligations. "Bare" geographic or genetic communities can become "true" communities if they meet the institutional and personal conditions of

$\begin{array}{ll}\text { 83. } & \text { P. } 53 . \\ 84 . & \text { P. } 152 . \\ 85 . & \text { P. } 188 . \\ 86 . & \text { P. } 212 .\end{array}$ 
equal concern for each individual. ${ }^{87}$ In a style redolent with MacIntyrean motifs, ${ }^{88}$ Dworkin blends traditional social practices with principles of justice to establish a just community. However, even Dworkin's "true" community is a pale and anemic shadow of its full-blooded ideal. It is little more than an aggregate of self-interested individuals who band together to facilitate the pursuit of their own life projects-a relation of strategic convenience and opportunism rather than mutual commitment and support. Stripped of its visual rhetoric, it amounts to the very Lockean social contract of the conditional kind that Dworkin is at pains to discredit and disclaim. People are bound in associative arrangements that are "contingent on reciprocity." I I need only count others as friends if and so long as they extend the same concern to me. Moreover, I am morally free to act as I choose so long as I do not interfere with others' similar rights: I need only consider others' interests when our rights compete or our projects overlap. Indeed, Dworkin's metric of comparative financial harm ${ }^{00}$-I should forgo my plans when the amount others would be prepared to pay me not to continue would be greater than that I am prepared to pay others not to continue with theirs-is premised on exactly the kind of moral accounting that communal aspirations, if they are to be meaningful, must aim to resist: "If I forgo an opportunity in one case, because the relative loss to you would be greater, this should be entered to my credit in a moral ledger against the next decision I (or you) have to make."

This moral discourse of costs and benefits is surely anathema to the citizen committed to the community. It is the language of economic transactions and not of personal relations. It makes morality a matter of quantitative dealings and not qualitative experiences. The "moral ledger" reveals an ethical bankruptcy that must be compensated for and not embraced by a communal mode of social life; the standard of a community's moral well-being is not measured by its balance of moral trade. In the "bare" community of moral ledgers, any possibility of nurturing warm habits of the heart is lost in the cool calculations of the head. Moral accounting is the language of impoverishment and not empowerment. Within Law's Empire, communal and interpersonal relations are haunted by Emerson's chilling protest: "Then, again, do not tell me, as a good man did to-day, of my obligation to put all poor men in good situations. Are they my poor?"'?2

Not only does Law's Empire transact in a devalued moral coinage, but

87. See supra text accompanying note 47.

88. See A. MAcintyre, AFter VirTue (2d ed. 1934).

89. P. 198.

90. See supra text accompanying note 63 .

91. P. 306 .

92. R.W. EMERSON, Self-Reliance, in EsSAys AND LeCTuRes 262 (1983). 
it is also profoundly elitist and undemocratic. Under the ostensibly liberating tutelage of principle, there functions a subtle regime of oppression. Despite paying lip-service to "a theater of debate," about accepting and assuming political obligations and not about participating in the making of them. Rationality and expertise are the political order of the day. Imperial citizenship is about "fidelity to a scheme of principle each citizen has a responsibility to identify" exploring what these principles require." as no surprise, for empires are not known for their popularist concerns and participatory initiatives. In Law's Empire, judges have been elevated to the rank of moral prophets and philosopher monarchs. For citizens, politics has become a spectator sport. Yet, philosophy has no monopoly on truth and justice; its privilege is contrived and invalid. Our images of justice should not be the philosopher's gift, but should be produced through the sweat of our own democratic brows. In that way, they are likely to be valued more.

Law's Empire is an unadulterated form of oligarchic politics. Its stunted character of public discourse confirms Rousseau's dictum that, without robust debate and active citizens, below the rulers (i.e., Indy and Hercules) there is nothing but debased slaves. ${ }^{96} \mathrm{~A}$ community worthy of its name is not based on a set of abstract commitments to universal principles, but is grounded in the experience of interpersonal relations and ties. It is more of an emotional and shared existence than a disembodied and cognitive enterprise of rule by judicial proconsuls. Abstract knowledge is second- or third-hand; the abstract gossip of philosophical experts is no substitute for the engaged conversation of ordinary citizens. Principled discourse represents one small part of the dramatic dialogue that composes communal life and politics. Individuals are products of their social contexts, not historical entities of given preferences. As such, people must be encouraged to participate in and revise the social context through which their preferences are cultivated and questioned. As Richard Rorty so wonderfully put it, "persons have dignity not as internal luminescences, but because they share in contrast-effects." ${ }^{\text {"97 }}$ Politics is legitimated by participation and not principle.

The oppression and transparency of Dworkin's conception of community is beautifully captured in the plaintive scenes between father and daughter: "Does a daughter have an obligation to defer to her father's

\footnotetext{
93. P. 211.

94. P. 190 (emphasis added).

95. P. 188 (emphasis added).

96. See J. Rousseau, The Social Contract bk. II (J. Cole trans. 1950).

97. Rorty, Postmodernist Bourgeois Liberalism, in Hermeneutics and PRAXIS 218 (R. Hollinger ed. 1985).
} 
wishes in cultures that give parents power to choose spouses for daughters but not sons?"8s In a few short frames, Dworkin inadvertently captures the oppressive power relations that characterize Law's Empire; the familial setting is the wider political environment writ small, the private is the public. Assuming that in such cultures it is possible that "women are as important as men," paternalism can place strong obligations on a daughter. Dworkin concludes that in such circumstances, "a daughter who marries against her father's wishes . . . has something to regret. She owes him at least an accounting, and perhaps an apology, and should in other ways strive to continue her standing as a member of the community she otherwise has a duty to honor." ${ }^{100}$ Surely little needs to be said about the powerful and destructive dynamic at work; it is oppression of women masquerading as traditional honor. What does her father owe her? How is he treating her as an equal? How has she participated in this decision? What is the source of her duty? Duty is assumed through mutual connections and not imposed in the name of principle.

Yet, despite its offensiveness, this familial cameo is not aberrational. In Law's Empire, political life is organized as a grand national seminar. Evoking traditional jurisprudential symbolism à la Rostow, ${ }^{101}$ Dworkin casts judges as republican schoolmasters. Deciding upon the agenda and appropriate principles of justice in the cloistered atmosphere of the faculty common room, they transmit these values to the masses. Education becomes an alienating exercise in the rote learning of principled values; any attempt to encourage participation in or questioning of the formation or wisdom of these values is deplored. Education becomes the heart and muscle of social control and imperial conformity. The cult of the teacher/ father-figure serves to foster an inegalitarian sense of cognitive and moral superiority. This is not the stuff of the civic good life, but the hierarchical caste of empire. In a true community, all imperial trappings would be banished: Political knowledge would become a matter of practical, popular, and interrelational judgment that works to recast the world in its own developing and experimental image. Dworkinian philosophers would be exiled, for " $[\mathrm{g}]$ enuine philosophers are . . . commanders and legislators: they say, 'thus it shall be . . . ."102 Democracy abhors such politics.

\footnotetext{
98. P. 204.

99. Id. (emphasis added).

100. P. 205.

101. See Rostow, The Democratic Character of Judicial Review, 66 HARv. L. Rev. 193, 208 (1952).

102. F. Nietzsche, Beyond GoOd AND EviL \#211 (W. Kaufmann ed. 1966).
} 


\section{Off the Plateau \\ (From The Lizard)}

... The least satisfying encounter in Indy's adventure is the encounter that never takes place-his jurisprudential stand-off with the Glinsk. These are a modern and eclectic bunch of academics (a.k.a. The Crits) who maintain, so Dworkin thinks, a global internal skepticism toward Law's Empire: They deny the possibility of a coherent and unified interpretation of legal practice. Over the past decade, they have generated a rich and radical body of tribal literature. The story they tell is vast and varied. Its textual heart lies in the historical insistence that legal reasoning is not only indeterminate and contradictory, but serves to sustain political hierarchy and social domination. To avoid a geniune locking of juristic horns, Indy relies on the full range of his rhetorical skills.

As a prelude to being conquered, the Glinsk are first divided by a classic piece of Dworkinian obscurantism. Without bothering to identify any real-life skeptics and without reference to skepticism's own intellectual traditions, Indy distinguishes the Glinsk from the non-metaphysical Extskeps who make the external and disengaged claims that do not challenge the conduct of interpretation, but merely reject its epistemological validity. ${ }^{103}$ In effect, Indy confers on the Glinsk the status of official opposition. Yet his distinctions are crude and contrived; they do not respect the intellectual or genealogical self-understanding of the Skeptical Nation. The Glinsk and the Extskeps are not genetically pure, but interbreed in many complex ways. It is typical of Indy's imperial anthropology that he classifies and comprehends all others in accordance with his own philosophical and epistemological lights. Conveniently forgetting his own critical injunction that "there is no position of interpretive neutrality," he stands outside the skeptical tradition and imposes his own political predispositions on their tribal traditions. Indy fails to extend that interpretive generosity he demands others extend to him: He refuses "to make of it the best possible example of the form or genre to which it is taken to belong." ${ }^{104}$ As a story of contradiction and ideology, he does not read it in its best light by interpreting it as a tale of coherence and ideals. If only he were anything approaching consistent, Indy would find that his interpretive weapons cut both ways.

Having converted the Glinsk into an interesting instance of scholarly counter-culture, he proceeds to patronize them. Indy confesses that "[t]heir work is useful to Hercules, and he would neglect it at his

103. Pp. 76-86.

104. P. 52. 
peril," ${ }^{105}$ but he concludes, without actually examining any arguments, that they "have so far been spectacular and even embarrassing failures." ${ }^{108}$ Indy's style is philosophical debate by fiat, a matter of imperial decree rather than engaged argument. He pats the Glinsk collectively on the head and tells them to come back when they have grown up. He suggests that the Glinsk have struggled to demonstrate only that a flawed account of law fits as well as a smoother one; he argues that "[n]othing is easier or more pointless." 107 The task of jurisprudential manhood, according to Indy, is to "show that the flawed and contradictory account is the only one available."108 This is exactly the task that the Glinsk have undertaken and accomplished. Indy's decision to note rather than face them is not an act of colonial superiority, but a gesture of jurisprudential cowardice. Indy may be the present king of the jurisprudential castle, but the dirty rascals are already inside the gates.

Even assuming that Dworkin was prepared to face the Critical challenge, he has stage-managed his enactment of the jurisprudential Armageddon so well that The Crits would fare no better than the Conventionalist or Pragmatist forces. The "plateau" of conflict ${ }^{100}$ is situated in a theoretical environment and at a level of philosophical abstraction that preempt their participation. Indeed, it is this very kind of apolitical theorizing, with its loaded epistemological standards and reduced hermeneutic horizons, that the Critical project is most at pains to deconstruct and reject. ${ }^{110}$ With its conditions of "individual right" and "past decisions of the right sort," to expect The Crits to agree to such a venue is like asking a fish to swim in a pool of oil so that it will swim faster and with less resistance than in water....

\section{A Wicked Weakness \\ (From The Popular Press)}

... the flashbacks to the horrible days of Nazi Germany and Civil War America are particularly disturbing. The "too wicked" scenes of institutionalized slavery and anti-semitism are brutally graphic. Yet Dworkin's technique and its theoretical underpinnings are at their weakest and most exposed in these moments. Although still on the side of the gods,

105. P. 273.

106. P. 274.

107. Id.

108. Id.

109. See supra text accompanying note 30 .

110. See Hutchinson \& Monahan, Law, Politics, and The Critical Legal Scholars: The Unfolding Drama of American Legal Thought, 36 STAN. L. REv. 199 (1984); Hutchinson, Part of an Essay on Power and Interpretation (With Suggestions on How To Make Bouillabaise), 64 N.Y.U. L. REv. 830 (1985). 
Hercules shows that he might be human, all too human, and Indy seems uncharacteristically stumped.

The central question is whether wicked legal systems generate legal rights and whether judges must enforce such rights. Did slave owners have the right to the return of their escaped slaves? Did a judge have to confiscate the property of Jews at the request of Aryans? Hercules is sorely troubled by these cases; not simply because he finds them intolerable, but because legal integrity seems to warrant their answer in the affirmative. A good faith reading of the library of legal materials points to the existence of such rights. Yet, although Hercules seems to have met his Waterloo, Indy slips him another distinction that allows him to elude such an ignominious end:

A full political theory of law . . . includes at least two main parts: it speaks to both the grounds of law-circumstances in which particular propositions of law should be taken to be sound or true-and to the force of law - the relative power of any true proposition of law to justify coercion in different sorts of exceptional circumstance . . . .

-...

... Philosophies of law are . . usually unbalanced theories of law: they are mainly about the grounds and almost silent about the force of law. ${ }^{111}$

. . If a judge's own sense of justice condemned [the grounds of law] as deeply immoral . . ., he would have to consider whether he should actually enforce it . . ., or whether he should lie and say that this was not the law after all, or whether he should resign. The principle of integrity in adjudication, therefore, does not necessarily have the last word about how the coercive power of the state should be used. But it does have the first word, and normally there is nothing to add to what it says. ${ }^{112}$

Hercules (and, therefore, Indy) may have won this particular battle, yet lost the legal war. The escape turns out to have been bought at too high a price-to be a Pyrrhic victory. Shaved so thin, the transparent legal integrity will be of little use in future skirmishes. The "judge's own sense of justice" is regnant. This means that judges are unconstrained by past judicial and legislative decisions if they consider them sufficiently wicked. But wickedness is a notoriously contested concept; one judge's iniquity is another's equity. In circumstances that are not "exceptional," the primacy of the judge's conscience is not fatal because "the principle of integrity" will provide the necessary institutional constraint. But, in "exceptional circum-

111. Pp. $110-11$.

112. P. 219. 
stances," the judge's "own sense of justice" will be irresistibly paramount. Indeed, contrary to Indy's later statements, the dreaded Marxist or fascist (or feminist or Crit or whoever) would "qualify for the [jurisprudential] contest." ${ }^{113}$ Furthermore, the threshold requirement of "exceptional circumstance" operates as no check at all, as it would be logically impossible to ask "the principle of integrity" to determine the conditions of its own applicability. Accordingly, on a showing of wickedness, a judge is free to "lie," "resign," or "refuse to enforce the law."

Recall the anguish of the McLoughlin Challenge. ${ }^{114}$ Suppose a judge believed that any system that did not provide full compensation for all victims of misfortune in all circumstances was wicked because failing to compensate would be to treat people's lives as mere commodities to be traded in the market of accidents. Or imagine a judge who believed that no one should ever be required to compensate another for injury unless it was deliberately caused because to do otherwise would be to curtail people's liberty. In his "morally pluralistic society," comeback against such judges. He must rely on the fact that "legal argument takes place on a plateau of rough consensus." ${ }^{\text {"116 }}$ When that fragile consensus breaks down, Law's Empire will begin to crumble. The imperial foundations, supposedly formed from the hard rock of principle, will be revealed to rest upon the shifting sands of ideological consensus. Dworkin's complacency about that consensus is born of a splendid isolation from popular movements. He depends on the moral inertia of the undifferentiated political center and the tyranny of the familiar; "no one really thinks the law wicked or its authors tyrants." ${ }^{117} \mathrm{Sez}$ who? Has Dworkin spoken to many women, gays, blacks, or Indians recently? Law's Empire deals with the deprived and disadvantaged in society by simply pretending that they do not exist-Q Qu'ils mangent de la brioche.

\section{Cheap Shots}

\section{(From The Hollywood Times)}

. . . it is an old trick of pornographic film producers to announce at the beginning of their celluloid creation that "this is not a pornographic film." This, of course, has all the subtlety of waving a red rag at a bull, and none but the complicit or gullible are convinced. Law's Empire is far from the seedy world of the porn merchants. Yet Dworkin employs a similar tactic of avoidance, albeit in more sophisticated style. In the opening

113. P. 408.

114. See supra note 25 and text accompanying notes 56-57.

115. P. 213.

116. Pp. 108-09.

117. P. 111. 
scenes, Dworkin explains that his project "centers on formal adjudication, on judges in black robes, but these are not the only or even the most important actors in the legal drama." 118 As in the pornographic film trade, judicial fetishism is no less a fetish because it is dignified with euphemistic garb. The whole work is an indulgent exercise in judge-watching. The momentary parade of "legislators, policemen, district attorneys, welfare officers, schoolboard chairmen ... bankers and managers and union officers"118 merely serves to emphasize their complete absence from Indy's adventures and to highlight the judicial center of Law's Empire.

From these opening moments, the production hardly ever moves beyond escapist fantasy: Law's Empire is a travelogue through the intellectual landscape of Dworkin's jurisprudential mind. His psychic opponents bear little resemblance to their real-world counterparts. Indeed, Dworkin concedes that the juristic dissidents are little more than fragments of his own fertile imagination: While "each [deliberately constructed conception of legal practice] captures themes and ideas prominent in that literature," the conceptions "are not meant precisely to match the 'schools' of jurisprudence . . . and perhaps no legal philosopher would defend [them] exactly as I describe [them]."120 Although his motives might be honorable, the result of Dworkin's effort is a massive act of condescension and arrogance. Dworkin offers his reconstituted versions of legal thought as "more illuminating than the stale battles of the texts."121 Yet it is difficult to escape the conclusion that he "constructs" and "illuminates" his adversaries only to defeat them more easily. It is a tempting but illegitimate technique.

As in the musicals of the 1930s, Dworkin seems to be hoping that Indy will lure back many of the scholarly malcontents to the legal fold with his own modernist brand of jurisprudential romance. In a cleverly cast and lavishly choreographed production, the insouciant Hercules steals the show with his effortless combination of urbane philosophical charm and rough-house skills of realpolitik. Yet, when you have seen one Indiana video, you have seen them all; the intended mythic massage for the bruised judicial ego is in danger of becoming a gratuitous pummelling. The appeal of Indy's bootstrap trickery is decidedly short-lived and ultimately self-defeating. The constant effort to inject the vivid colors of heroic adventure into the dreariness of daily life in contemporary society defeats itself by heightening future expectations and existing frustrations. Dramatic tension turns to tedium and what Dworkinian lawyers consider brilliant becomes merely boring; there is a limit to the fascination of

118. Id.

119. P. 12.

120. Id.

121. P, 94. 
watching lawyers roll up the stone of Sisyphus by dint of the paring and parsing of endless tomes of law reports and philosophical treatises. The identification of universal principles in the soil of parochial facts is not the mark of the critical thinker, but the obsession of the formalistic gardener. While the achievement of turning this task into an elevated art form is not to be underrated, its credibility and value are beginning to wear extremely thin.

\section{HARPOON'S INDEX}

It matters how judges decide cases. ${ }^{122}$

No department of state is more important than our courts . . . ${ }^{123}$

The United States is a more just society than it would have been had its constitutional rights been left to the conscience of majoritarian institutions. ${ }^{124}$

[T] he social revolution that $[$ Brown] announced was both national and foundational.

The courts developed a distinct jurisprudence of racial integration, neither entirely successful nor entirely coherent, but nevertheless largely a credit to law. ${ }^{\mathbf{1 2 5}}$

Percentage of black children who live below the poverty line: 47.3. ${ }^{128}$ Percentage of non-black Americans who say that there should be a law against interracial marriage: $28 .{ }^{127}$

Percentage of non-black Americans who say that blacks "should not push themselves where they are not wanted": $58 .{ }^{128}$

Chance that a white male in the U.S. will be murdered in a given year: 1 in $9927 . .^{129}$

Chance that a black male in the U.S. will be murdered in a given year: 1 in $1539 .{ }^{130}$

122. P. 1.

123. P. 11.

124. P. 356.

125. P. 391.

126. United Siates Dep'r of Commerce, Bureau of the Census, Statistical Abstract OF THE UNITED STATES 1985, at 455 (105th ed. 1984) [hereinafter 1985 ABSTRACT] (1982 data).

127. T. Smith, A Compendium of Trends on General Social Survey Questions 169-70 (1980) (1977 data).

128. Of 751 white respondents, 434 agreed "strongly" or "slightly" to the statement. NATIONAL Opinion Research Center, General. Social Survey (Question 126, Feb. 4, 1985).

129. 1985 ABSTRACr, supra note 126 , at 170 (10.4 per 100,$000 ; 1981$ data).

130. Id. (64.8 per 100,$000 ; 1981$ data). 
Percentage of black high school graduates over 16 who are unemployed: 18.3. ${ }^{131}$

Percentage of white high school dropouts under 25 who are unemployed: $15.2 .^{132}$

Percentage of blacks unemployed in 1984: 17.2. ${ }^{133}$

Percentage of whites unemployed in 1984: 7.2.134

Percentage increase in ratio of black to white unemployment rates between 1965 and 1984: 20. ${ }^{\text {195 }}$

Percentage of elected officials who were black in 1985: $1.2 .{ }^{136}$

Earnings of black families as a percentage of earnings of white families: 56. ${ }^{137}$

Percentage of black families below poverty level: $32.4 .^{138}$

Percentage of white families at poverty level: $9.7 .{ }^{139}$

Ratio of male black children dying in first year of life to male white children dying in first year of life: 1.8 to $1 .^{140}$

Percentage of persons in New Orleans who are black: $50{ }^{141}$

Percentage of qualified applicants for police in New Orleans who are black: $40 .{ }^{142}$

Percentage of police officers in New Orleans who are black: $2 .^{143}$

Chance of an American being in state prison on any given day: 1 in 800.144

Chance of a black male American being in state prison on any given day: 1 in $33 . .^{148}$

Median income for all black families in 1983: $\$ 14,506 .^{146}$

Median income for all white families in 1983: $\$ 25,757 .{ }^{147}$

Median income of black families as a percentage of that of white families in 1970: $61 .{ }^{148}$

\footnotetext{
131. Id. at 407 (1984 data; comparable figure for whites is $7.4 \%$ ).

132. Id. (1984 data; comparable figure for blacks is $27.3 \%$ ).

133. Id.

134. Id.

135. Id. $(8.5 / 4.3$ in $1965 ; 17.2 / 7.2$ in 1984$)$.

136. Joint Cfinter for Political Studies, Black Elected Officials 11 (1985). Blacks constitute $10.8 \%$ of the voting age population. Id.

137. Clauss, Keynote Address, 13 N.Y.U. Rev. L. \& Soc. Change 225 (1985).

138. 1985 ABS'RACT, supra note 126, at 456 (1983 data).

139. Id.

140. Id. at 71 (2165 blacks per 100,000; 1182 whites per 100,000; 1981 data).

141. Clauss, supra note 137 , at $227-38$.

142. Id.

143. Id.

144. See Blumstein, On the Racial Disproportionality of U.S. Prison Populations, 73 J. CRIM.

L. \& CRIminology 1259, 1260 (1982).

145. Id.

146. 1985 ABSIRAcr, supra note 126 , at 446.

147. Id.

148. Id. (black family income: $\$ 16,111$; white family income: $\$ 26,263$ ).
} 
Median income of black families as a percentage of that of white families in 1983: $56 . .^{140}$

Percentage increase in black unemployment rate from 1972-1982: 82. ${ }^{150}$ Percentage increase in white unemployment rate from 1972-1982: 69.151

Of course, this stark listing of data does not refute or conclusively confound Dworkin's claims. However, it does present a formidable challenge and counterpoint to the typical lawyer's empirical naivete (or arrogance) that Dworkin's extravagant statements reflect. With almost no supporting evidence, lawyers make the most sweeping and smug claims for the instrumental impact and efficacy of adjudication; when the courts speak, the world not only sits up and listens, but changes in line with judicial expectations. The small amount of evidence available strongly suggests the contrary view that litigation and adjudication are of marginal importance to global change. ${ }^{162}$ Revealing how Dworkin slides over a controversial issue, the cited data cast the gauntlet firmly at his feet, and challenge him to support his intuitive and admittedly widely shared claims. For instance, the literature on Brown is sizeable and casts severe doubt on the usual lawyerly view that the Supreme Court's decision was a major victory in the continuing battle against American racism. ${ }^{163}$ To put it another way, if Brown had been decided differently, would the unfolding of events have been much changed? Dworkin must confront this criticism.

The attempt to isolate and assess the impact of the courts is notoriously difficult. It is plainly ridiculous to abstract the courts from American history and to point to the mixed performance of the remaining branches of government. The evidence from other countries without constitutional review suggests that without the Supreme Court those other branches would take up much of the slack. Moreover, the performance of the legislative branch has been by no means as bad as is often thought and, over time,

149. Id.

150. Id. at 406 (1972 rate: $10.4 \% ; 1982$ rate: $18.9 \%)$.

151. Id. (1972 rate: $5.1 \%$; 1982 rate: $8.6 \%$ ).

152. These arguments are pursued at length and fully documented in Hutchinson, Charter Litigation and Social Change: Legal Battles and Social Wars, in Charter LITIGation (R. Sharpe ed. 1987, forthcoming).

153. See, e.g., Bachmann, Lawyers, Law and Social Change, 13 N.Y.U. Rev. L. \& Soc. Change 1, 17-21 (1985).

In making this argument, however, I must stress that I do not think that constitutional adjudication is an unimportant feature of social life. Although it is not important in the sense of causing anything to happen, adjudication represents a significant rhetorical mode of social ordering and control. As a potent mode of discursive action, it helps to structure the world in particular ways and to justify the existing conditions of social organization. On the Supreme Court's performance on racism, see Freeman, Legitimizing Racial Discrimination Through Anti-Discrimination Law: A Critical Review of Supreme Court Doctrine, 62 MINN. L. Rev. 1049 (1978); and, on the persistence of racism, Pettigrew, New Patterns of Racism: The Different Worlds of 1984 and 1964, 37 RuTGERs L. REV. 673, 700 (1985) ("Though older forms persist, the 'new patterns of racism' are more subtle, indirect and ostensibly nonracial."). 


\title{
Indiana Dworkin
}

stands up easily to comparison with the Supreme Court's contribution to American life. Also, even with its vaunted Constitution and judicial review, the United States has no better, and often a worse, record of dealing with the central problems of social injustice, like poverty and racism, than other comparable countries such as Canada, Australia, and the United Kingdom. Indeed, at certain crucial junctures in American history, like the abolition of slavery and the New Deal, the Supreme Court has hindered rather than facilitated change. ${ }^{154}$ It is a very sad comment on traditional jurisprudence, as championed by Dworkin, that its adherents are content with the most sweeping of unfounded generalizations; it puts their heralded virtues of rigor and sophistication into harsh perspective. Their only inadequate and pathetic response recalls a line from Chekhov: "[E]verything is peaceful and quiet and only mute statistics protest."

\author{
YOU'VE SEEN THE FILM. \\ YOU'VE HEARD THE REVIEWS. \\ NOW READ THE BOOK!
}

154. See, e.g., R. Cover, Jusitce Accused (1975).

155. Chrkhov, Gooseberries, in The Portable Chekhov 381 (1947). 
